\title{
Comunicação
}

[Communication]

\section{Perfil hematológico e avaliação eletroforética das proteínas séricas de cães com cinomose}

[Hematological profile and electrophoretic evaluation of serum proteins of dogs with canine distemper]

\author{
I.N.G. Silva ${ }^{1}$, M.I.F. Guedes ${ }^{1}$, M.F.G. Rocha ${ }^{1}$, C.M.O. Medeiros ${ }^{2}$, L.C. Oliveira ${ }^{2}$, \\ O.C. Moreira ${ }^{1}$, M.F.S. Teixeira ${ }^{1 *}$ \\ ${ }^{1}$ Faculdade de Veterinária - Universidade Estadual do Ceará \\ Av. Paranjana, 1700 Itapery \\ 60740-000 - Fortaleza - Ceará \\ ${ }^{2}$ Médica Veterinária Patologista Clínica
}

A cinomose, virose altamente contagiosa causada por um Morbillivírus (Koutinas et al., 2002), é considerada a doença de cães com a mais alta taxa de letalidade após a raiva (Appel e Summers, 1995). Para seu diagnóstico podem ser empregadas as técnicas de ELISA (BlixenkroneMoller et al., 1993), imunofluorescência (Megid et al., 2000) e RT-PCR (Saito et al., 2000; Gebara et al., 2004). Em virtude do custo, essas técnicas são pouco utilizadas. A maioria dos diagnósticos é feita baseando-se na história, sintomatologia e achados hematológicos (Mendonça et al., 2000). Outros recursos possíveis de serem utilizados no diagnóstico da cinomose são as pesquisas sobre a inclusão viral de Lentz e a eletroforese das proteínas séricas (Batista et al., 2000; Feitosa et al., 1997). Inclusões de Lentz representam o efeito citopático do vírus sobre a célula. Sua visualização em hemácias ou leucócitos confere ao diagnóstico um caráter definitivo (Feldman et al., 2000). A eletroforese das proteínas séricas, de uso rotineiro em laboratórios de patologia clínica humana, ainda é pouco solicitada na medicina veterinária.

O objetivo deste trabalho foi estabelecer o perfil hematológico e eletroforético de cães com cinomose.

Recebido para publicação em 12 de dezembro de 2002

Recebido para publicação, após modificações, em 21 de junho de 2004

*Autor para correspondência (corresponding author)

E-mail: mfteixeira@hotmail.com

${ }^{1}$ Cia. Equipadora de Laboratórios Modernos - CELM - São

Paulo

${ }^{2}$ Labtest Diagnóstica - Minas Gerais
Pesquisou-se a presença do corpúsculo de Lentz em 62 cães, provenientes da região metropolitana de Fortaleza - CE, com sintomatologia clínica característica de cinomose, utilizando-se esfregaços de sangue corados com panótipo rápido (Gurr, 1991). Os animais positivos ao teste foram sangrados por punção das veias cefálica ou jugular. As amostras de sangue foram coletadas em tubos com vácuo e anticoagulante (EDTA) para hemograma, e sem anticoagulante, para obtenção do soro.

No hemograma usou-se contador automático veterinário CC- $530^{1}$ e o diferencial de leucócitos foi feito em esfregaços sangüíneos. As proteínas séricas foram determinadas por refratometria e confirmadas pelo sistema colorimétrico de proteínas totais ${ }^{2}$. A eletroforese foi feita segundo metodologia de Naou (1999). Na comparação das características hematológicas e eletroforéticas utilizou-se o teste $\mathrm{t}$ de Student com $\mathrm{P}<0,01$.

Dos 62 cães suspeitos apenas em 13 (21\%) foram observadas inclusões virais de Lentz (Fig. 1). Segundo Jain (1993), essas inclusões são mais freqüentes em linfócitos, mas neste experimento foram observadas principalmente em neutrófilos. Embora elas sejam um achado transitório, sua visualização em hemácias e/ou leucócitos é mais freqüente durante a fase virêmica da infecção (Gossett et al., 1982). 


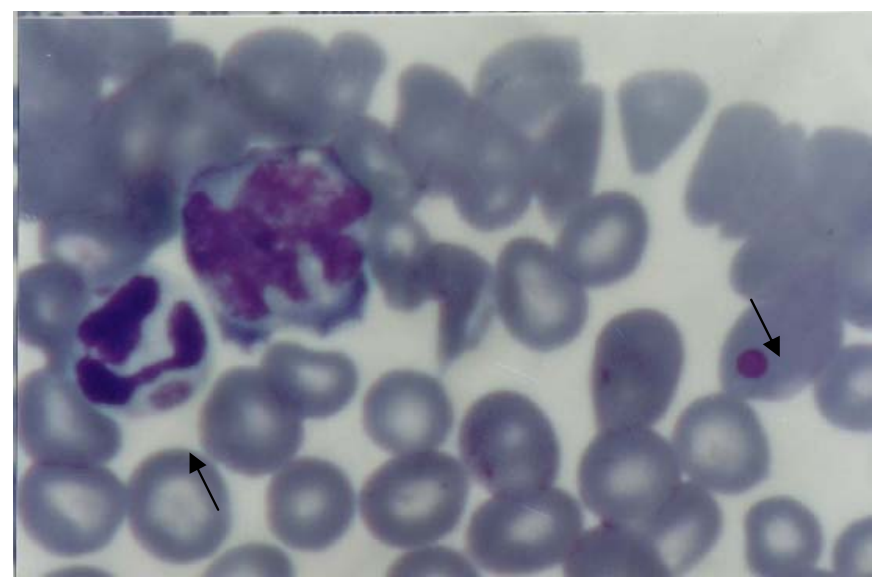

Figura 1. Inclusões de Lentz intra-eritrocitária e no citoplasma de leucócito (setas) de cães com suspeita clínica de cinomose.

Apesar das inclusões de Lentz já terem sido descritas em outras células (Headley e Graça, 2000) além das sangüíneas, Batista et al. (2000) e Alleman et al. (1992) relataram a presença pouco freqüente de corpúsculos de inclusão em cães com cinomose.

Sabe-se que a resposta hematológica varia também de um indivíduo a outro, bem como com a fase da infecção viral (Fenner et al., 1993). Neste trabalho, de acordo com os valores de referência preconizados por Jain (1993), no grupo dos animais positivos para cinomose, houve $61 \%$ de anemia, $46 \%$ de leucopenia, $8 \%$ de leucocitose por neutrofilia, $54 \%$ de desvio a esquerda, $85 \%$ de linfopenia e $69 \%$ de trombocitopenia. A anemia observada confirma as observações de Jain (1993) em cães infectados experimentalmente e pode ser atribuída ao aumento da destruição dos eritrócitos ou pela diminuição de sua produção. A destruição é determinada pela presença do vírus no eritrócito ou pela deposição de imunocomplexos na membrana do eritrócito (Mendonça et al., 2000). A queda na produção pode ser atribuída a falência da medula devido ao estresse desencadeado pela doença (Meyer et al, 1995). $\mathrm{Na}$ maioria dos casos, os eritrócitos apresentaram-se normocíticos e normocrômicos e não houve sinais de regeneração medular (hemácias nucleadas, policromasia, anisocitose, corpúsculos de Howell-Jolly). Embora a contagem de reticulócitos seja a melhor forma de avaliação de regeneração eritrocitária (Meyer et al., 1995), neste experimento não foram realizadas contagens de reticulócitos mas apenas uma avaliação presuntiva, de acordo com a morfologia dos eritrócitos no esfregaço sangüíneo e com os valores de volume globular médio (VGM) e hemoglobina corpuscular media (CHGM).

O leucograma foi a característica mais variável. As contagens variaram de leucopenia a leucocitose. Infecções bacterianas oportunistas no trato alimentar e respiratório podem ser observadas em cães com cinomose. Isso justificaria a leucocitose por neutrofilia e o desvio a esquerda observados nos animais.

A linfopenia é uma característica consistente (Ettinger e Feldman, 1997) mas que pode estar ausente em alguns casos segundo Hoskins (1992). Cães filhotes, infectados experimentalmente com vírus da cinomose, desenvolveram marcada linfopenia (Feldman et al., 2000). Neste experimento, a linfopenia foi o achado mais freqüente e relevante.

A trombocitopenia também foi um achado freqüente nos animais estudados. O mecanismo responsável pela trombocitopenia associada a infecções virais na veterinária ainda é pouco conhecido. Sabe-se, apenas, que para o gênero 
Morbillivirus já se observou aumento de anticorpos anti-plaquetas (Feldman et al., 2000). A trombocitopenia foi provavelmente do tipo imunomediada com remoção das plaquetas pelo sistema retículo endotelial.

Lesões no epitélio intestinal causadas pelo vírus, com conseqüente diarréia, além da própria apatia determinada pela doença levam o animal a recusar o alimento. Dessa forma, a diminuição da ingestão protéica bem como o comprometimento intestinal são fatores determinantes na redução dos níveis séricos da albumina na cinomose (Kaneco et al., 1997). Isso justifica a hipoproteinemia observada na maioria dos animais. A elevação plasmática das globulinas é freqüente em várias reações inflamatórias e, em particular, o componente alfa 2 aumenta significativamente nas infecções bacterianas e víricas, notadamente na cinomose (Kaneco et al., 1997). Neste trabalho, em 100\% (13/13) dos casos houve diminuição da albumina e em 54\% (7/13), elevação da fração alfa 2 globulina. Em um cão foi observado aumento de fração gama. Este achado não é freqüente pois o vírus da cinomose tem caráter imunossupressor (Ettinger e Feldman, 1997). O aumento da fração globulínica foi inclusive refletido no hemograma desse cão, onde foi observado "rouleaux" eritrocitário.

Com base nos dados desta investigação, anemia, leucopenia, trombocitopenia, hipoalbuminemia e elevação da fração alfa-2 foram significativas e, portanto, esses achados hematológicos e eletroforéticos podem ser utilizados pelos clínicos veterinários como recursos diagnósticos auxiliares na cinomose canina.

Palavras-chave: cão, cinomose, hemograma, eletroforese, diagnóstico

\section{ABSTRACT}

The hematological and serum proteins electrophoretic profiles of 13 dogs with distemper (Lentz inclusion body in leukocytes) were studied. The most frequent hematological findings were: normocitic normocromic anemia (61\%), leukopenia (46\%), left shount (54\%), trombocytopenia (69\%) and lymphopenia (85\%). Electrophoretic analysis of serum proteins showed hypoproteinemia (54\%), with reduced albumin and increased alfa-2 globulin. These findings can be used to support the clinical diagnosis of canine distemper.

Keywords: canine distemper, hemogram, electrophoresis, diagnostic

\section{REFERÊNCIAS BIBLIOGRÁFICAS}

ALLEMAN, A.R.; CHRISTOPHER, M.M.; STEINER, D.A. et al., Identification of intracytoplasmic inclusion bodies in mononuclear cells from the cerebrospinal fluid of dog with canine distemper. Vet. Pathol., v.29., p.84-85, 1992.

APPEL, M.J.G.; SUMMERS, A. Patogenicity of morbilliviroses for terrestrial carnívores. Vet. Microbiol., v.44, p.187-191, 1995.

BATISTA, V.S.; MOURA, M.A.; REIS, R.R.R. et al. Ocorrência de corpúsculos de SinegagliaLentz em esfregaços sangüíneos de 70 cães com suspeita clínica de cinomose. Rev. Bras. Ciên. Vet., v.7, p.115, 2000. Suplemento.

BLIXENKRONE-MOLLER, M.; SVANSSON, V.; HAVE. P. et al. Studies on manifestations of canine distemper virus infection in an urban dog population. Vet. Microbiol.. v.37, p.163-173, 1993.

ETTINGER, S.J.; FELDMAM, E.C. Tratado de medicina interna veterinária - moléstias do cão e do gato. 4.ed. São Paulo: Manole, 1997. v.1, p.576-581.

FEITOSA, M.M.; FEITOSA, F.L.F.; KOHAYAGAWA, A. et al. Avaliação física, citológica, de proteínas e determinação qualitativa de globulinas do líquor de cães normais e com encefalites por cinomose. Braz. J. Vet. Res. Anim. Sci., v.34, p.147-151, 1997.

FELDMAN, B.F.; ZINKL, J.G.; JAIN, N.C. Schalm's veterinary hematology. 5.ed. Lippincott Williams \& Wilkins, 2000. 787p.

FENNER, F.J.; GIBBS, E.P.J.; MURPHY, F.A. Veterinary virology. 2.ed. Califórnia: Academic, 1993.

GEBARA, C.M.S.; WOSIACKI, S.R.; NEGRÃO, F.J. et al. Detecção do gene da nucleoproteína do vírus da cinomose canina por RT-PCR em urina de cães com sinais clínicos de 
cinomose. Arq. Bras. Med. Vet. Zootec., v.56, p.480-487, 2004.

GOSSETT, K.A.; MACWILLIAMS, P.S.; FULTON, R.W. Viral inclusions in hematopoietic precursors in a dog with distemper. J. Am. Vet. Med. Assoc., v.181, p.387388, 1982.

GURR, E. Syntetic dyes in biology, medicine and chemistry. London \& New York: Academic, 1971.

HEADLEY, S.A.; GRAÇA. D.L. Canine distemper: epidemiological findings of 250 cases. Bras. J. Vet. Res. Anim. Sci., v.37, p.136140, 2000.

HOSKINS, J.D. Pediatria veterinária: cães e gatos até seis meses de idade. São Paulo: Manole, 1992.

JAIN, N.C. Essentials of veterinary hematology. Philadelphia: Lea \& Febiger, 1993.

KANECO, J.J.; HARVEY, J.W.; BRUSS, M.L. Clinical biochemistry of domestic animals. 5.ed. California: Academic, 1997.

KOUTINAS, A. F.; POLIZOPOULOU, Z. S.; BAUMGAERTNER, W. et al. Relation of clinical signs to pathological changes in 19 cases of canine distemper encephalomyelitis. J. Comp. Pathol., v.126, p.47-56, 2002.

MEGID, J.; NOZAKI, C.N.; FILHO, O. A. et al. Positividade a imunofluorescência direta (IFD) em diferentes tecidos de cães clinicamente suspeitos de cinomose. Rev. Bras. Ciên. Vet., v.7, p.114, 2000. Suplemento.

MENDONÇA, R.B.; PAGANI, F.F.; MOREIRA DE SOUZA, A. et al. Respostas hematológicas em cães naturalmente infectados pelo vírus da cinomose: estudo retrospectivo de casos. Rev. Bras. Ciên. Vet., v.7, p.114, 2000. Suplemento.

MEYER, D.J.; COLES, E.H.; RICH, L.J. Medicina de laboratório veterinário interpretação e diagnóstico. São Paulo: Roca, 1995.

NAOUM. P.C. Eletroforese - Técnicas e diagnósticos. 2.ed. Livraria Santos Editora, 1999.

SAITO, T.B.; ALFIERI, A.A.; ALFIERI, A.F. et al. Diagnóstico laboratorial de diferentes fases clínicas da cinomose canina através da técnica de RT-PCR. Rev. Bras. Ciên. Vet., v.7. p.115. 2000. Suplemento. 